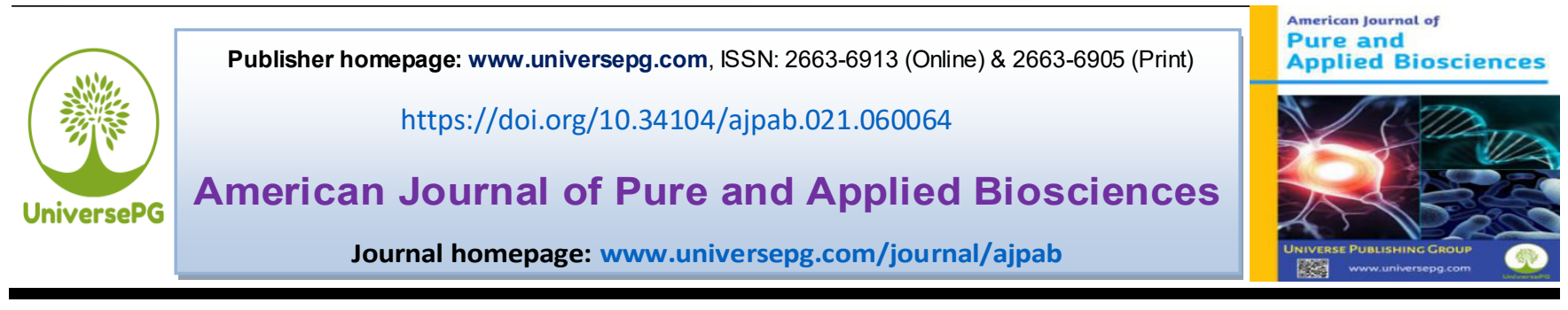

\title{
In Vitro Growth of Sunflower (Helianthus annuus) via Direct Organogenesis
}

\author{
Kobirul Islam ${ }^{1,2}$, Tasnim Ahmed ${ }^{1 *}$ and Tarana Sharmin ${ }^{1}$ \\ ${ }^{1}$ Department of Genetic Engineering \& Biotechnology, Science Complex Building, University of Dhaka, Dhaka-1000, \\ Bangladesh and ${ }^{2}$ Department of Biotechnology \& Genetic Engineering, Noakhali Science and Technology University, \\ Noakhali-3814, Bangladesh. \\ *Correspondence: tasnim.ahmed@du.ac.bd (Tasnim Ahmed, Assistant Professor, Department of Genetic Engineering \& \\ Biotechnology, Science Complex Building, University of Dhaka, Dhaka-1000, Bangladesh).
}

\begin{abstract}
Sunflower (Helianthus annuus) is a crop of increasing importance as a source of seed oil and proteins; nonetheless the number of studies on sunflower tissue culture is somewhat limited. The development of a competent in vitro direct organogenesis protocol involves important basic steps of regeneration. In our study, chemically sterilized sunflower seeds were planted on induction media and $52.54 \%$ germination efficiency was found. While the seeds were subjected to regeneration containing $2 \mathrm{mg} / \mathrm{L}$ of cytokinin, Benzyl Adenopurine (BAP) as well as $1 \mathrm{mg} / \mathrm{L}$ of auxin, Naphthalene Acetic Acid (NAA); shoot growth was observed with41\% regeneration efficiency. Non-sterilized seeds germinated but showed fungal growth on the surface of media resulting in no regeneration of sunflower plantlet. On the other hand, sterile seeds germinated less with little or no fungal growth leading to successful regeneration. Frequent regeneration of sterile sunflower seeds through direct organogenesis can contribute to enhanced micro-propagation of this plant.
\end{abstract}

Keywords: BAP, Cytokinin, Efficiency, Direct organogenesis, Explant, NAA, Regeneration, and Sunflower.

\section{INTRODUCTION:}

Sunflower, a Composite family member, is one of the major edible oil seed crops cultivating worldwide along with soybean, rapeseed and groundnut (Dagustu, 2018). Different factors include germplasm insufficiency, disease vulnerability, seed dormancy, recalcitrance to regeneration and abiotic factors cause the reduction of sunflower yield leading towards economic losses (Moghaddasi, 2011; Sujatha et al., 2012; Wingender et al., 1996). As there is limited use of native varieties due to genetic barriers in the reproduction process, conventional approaches fail to attain the desired growth and advancement of sunflower (Fiore et al., 1997; Gürel and Kazan, 1998; Shahen et al., 2019). Improved quality of sunflower plants can be UniversePG I www.universepg.com obtained by gene transfer from wild species and other crops. A consistent, functional in vitro regeneration method followed by transformation is mandatory for efficient gene transfer in sunflower (Firoz et al., 2016; Khatun et al., 2016; Hewezi et al., 2003).

Successful direct organogenesis guided regeneration of sunflower is adaptive and depend upon several factors including age, plant ecotype, environmental conditions and composition of culture media (Alibert et al., 1994; Deglene et al., 1997; Sarrafi et al., 1996). Direct organogenesis, which is the regeneration of plantlet without callus induction phase, is required in modern breeding to ensure reduced cost and rapidity in regeneration (Pourhosseini et al., 2013). Tissue culture dependent 
direct organogenesis from seeds have been done in various plants (Giovannelli et al., 2004; Zhu et al., 2007); but limited information has been reported regarding sunflower. Furthermore, sunflower tissue culture has been undertaken with different explants, including cotyledons, immature embryo, protoplast, shoot tips, hypocotyls ( Fiore et al., 1997; Dagustu, 2018).

Use of seeds as explant in case of sunflower regeneration is barely reported. Hence, in our study; we have performed in vitro direct organogenesis from cultured seed of sunflower. Seedlings obtained by this technique can be further used for genetic modification with less chance of contamination.

\section{MATERIALS AND METHODS:}

Sunflower seeds were brought from Bangladesh Agricultural Development Corporation (BADC), Meherpur, Bangladesh. Healthy seeds were subjected to germination. Seeds were incubated at $56^{\circ} \mathrm{C}$ for 3 hours. After that, seeds were dehusked followed by sterilezation. Dehusked seeds, which were washed with tap water for 5 times, were rinsed with $70 \%$ alcohol for 2 minutes followed by 20 minutes soaking in $40 \%$ sodium hypochlorite with two drops of tween 20 with frequent stirring. Then the seeds were washed 5 times using autoclaved distilled water in order to ensure removal of disinfecting residues. At last, the seeds were dried onto sterile whatman filter paper in lamina airflow until dried. These disinfected dried seeds were placed to germinate on induction media containing phytagel $(0.3 \%)$ under laminar airflow.

The sterilized seeds and the control (non-sterilized counterpart), were placed angularly in such manner that one-third of each seed dipped inside the media. The flask was sealed and placed in a light and temperature controlled plant growing system (constructed by Science Factory, DU) at $22^{\circ} \mathrm{C}$ and $16 / 8 \mathrm{~h}$ light/dark condition.After germination, seeds were transplanted to regeneration media (sucrose $3 \%$, macro-nutrients $5 \%$, micro-elements $0.5 \%$, myo-inositol $0.01 \%$, casein hydrolysate $0.05 \%$, BAP $2 \mathrm{mg} / \mathrm{L}$, NAA $1 \mathrm{mg} / \mathrm{L} ; \mathrm{pH} 5.8$ ). On the course of regeneration, 8 days old plantlets were soaked in antifungal cefotaxime solution $(200 \mathrm{mg} / \mathrm{ml})$ for 15 minutes and then transplanted onto new regeneration media.

\section{RESULTS AND DISCUSSION:}

Seeds started to germinate from day two. Sterilized seeds took 4-5 days to germinate and grew slowly. Non-sterilized seeds took 1-2 days to germinate and growth rate was higher. At the $5^{\text {th }}$ day of the germination, efficiency was recorded. Non-sterilized seeds indicated fungal growth on the upper surface of media after germination (not shown). However, sterile seeds showed lower germination (52.54\%) compared to those of non-sterile ones (70 \%) but showed less fungal growth (Table 1).

A possible reason behind the reduction of germination of sterilized seeds could be the inability of persisting the perilous influence of the chemical sterilants. At the $8^{\text {th }}$ day of germination, cefotaxime treated seedlings were shifted to regeneration. In the regeneration media the seedlings showed variability in growth pattern. At the $14^{\text {th }}$ day of germination, final regeneration efficiency was calculated (Table 1). It was noticed that plantlets regenerated from sterile seeds showed $41 \%$ regeneration efficiency and longer shoot (Fig 1.c). Higher shoot growth of sunflower was obtained due to elevated cytokinin-to-auxin ratio.

On the contrary non-sterilized germinated seeds failed to regenerate (Table 1) (Fig 1.d) since fungal contamination might occur from the seeds.In our study, sunflower culture was a challenge due to frequent fungal contamination. It was reported that cultivation of sunflower could face many constrains including microbial infection, precocious flowering, reduced rooting, hyperhydricity (Taški-Ajduković and Vasić, 2005). In spite of the challenges, we were successful to regenerate sunflower seedlings at in vitro conditions.

Table 1: Seed germination and regeneration

\begin{tabular}{cccccc} 
Seed Types & $\begin{array}{c}\text { Total } \\
\text { Seeds }\end{array}$ & $\begin{array}{c}\text { Germinated } \\
\text { Seeds }\end{array}$ & $\begin{array}{c}\text { Germination } \\
\text { Efficiency }(\boldsymbol{\%})\end{array}$ & $\begin{array}{c}\text { Regenerated Plant } \\
\begin{array}{c}\text { Regeneration } \\
\text { Efficiency }(\%)\end{array}\end{array}$ \\
\hline Sterilized & 118 & 62 & 52.54 & 48 & 41 \\
\hline Non-sterilized & 50 & 35 & 70 & 0 & 0 \\
\hline
\end{tabular}


$\mathbf{A}$

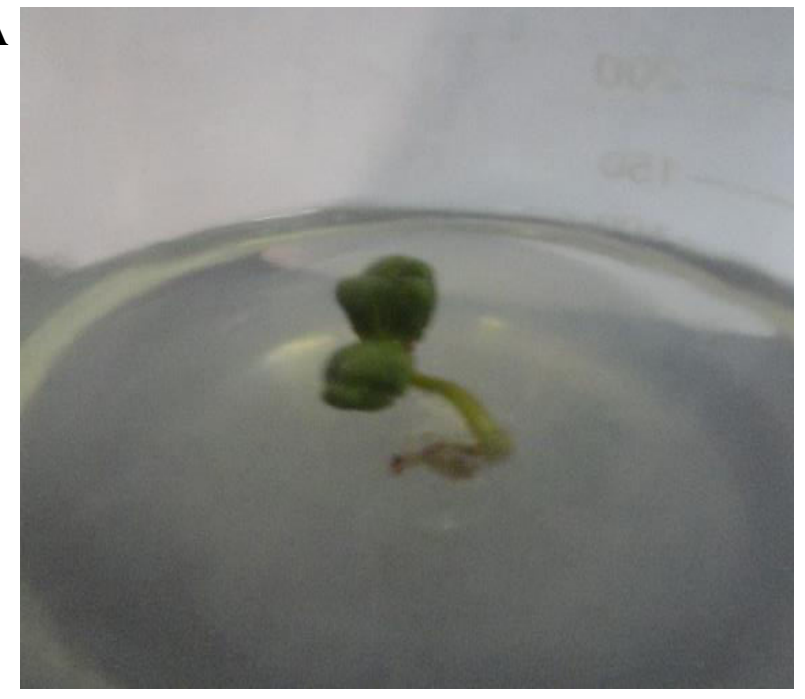

C

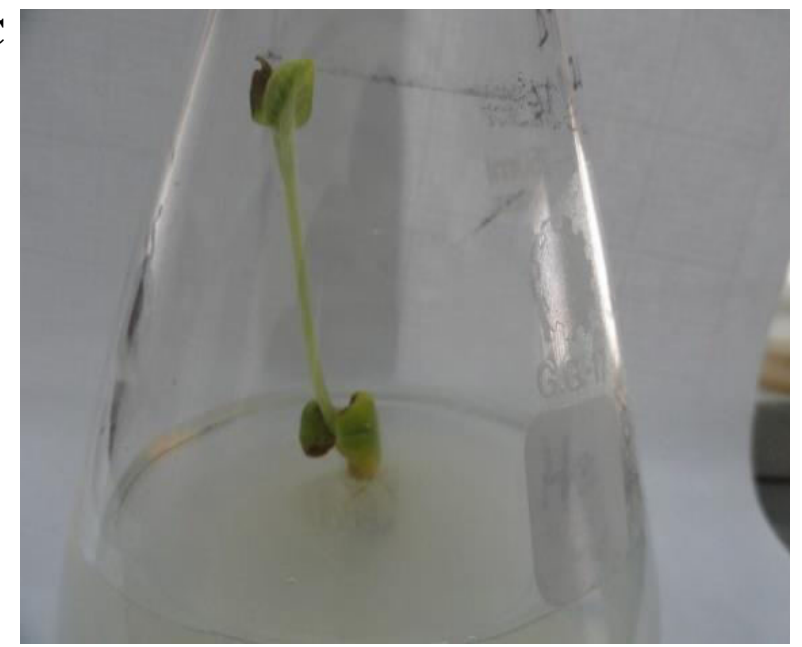

B

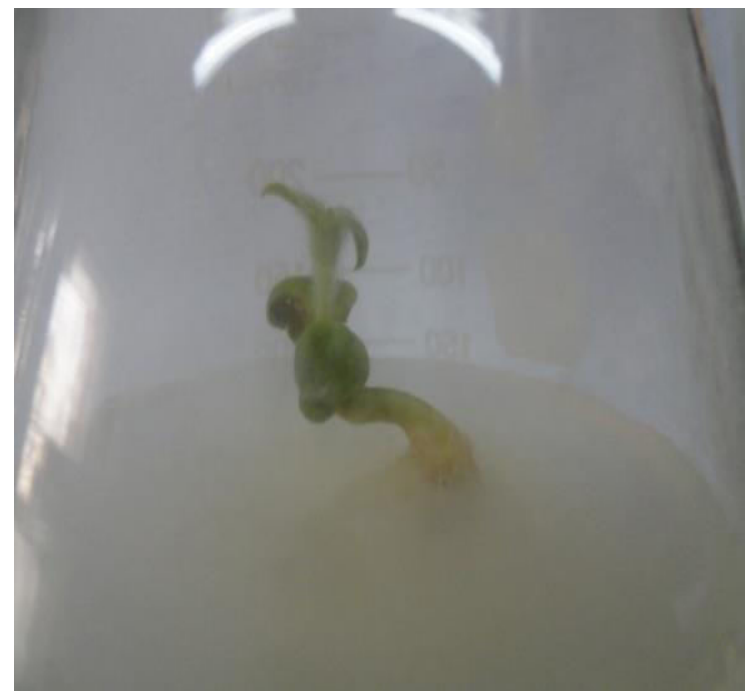

D

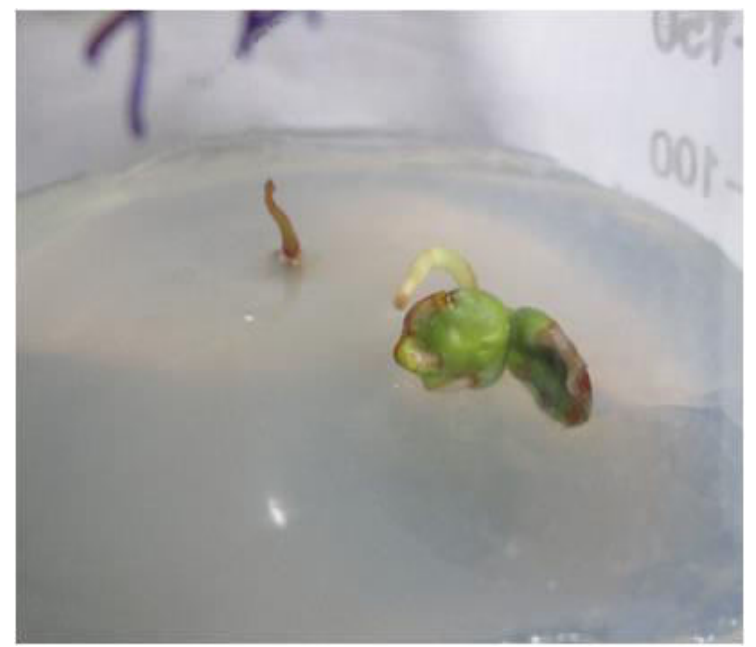

Fig1: Direct organogenesis of sunflower plants from seed explants. (A-C) Six, ten- and fourteen-days old plantlet of the germinated sterile seeds; (D) Germinated non-sterile seeds which failed to regenerate. Cytokine and auxin ratio during regeneration, $\mathrm{BAP}: \mathrm{NAA}=2: 1$.

\section{CONCLUSION:}

Direct organogenesis can increase the rapidity of plant regeneration and reduce the cost. In vitro direct organogenesis of sunflower using seed as explant can overcome environmental constrain. Also, sterile plantlets/plants can be developed by this method. Furthermore, these plantlets can be utilized for genetic transformation by particle bombardment or other biotechnological process and produced at large scale by micropropagation. Hence, the study we performed is important in plant biotechnology.

\section{ACKNOWLEDGEMENTS:}

The research work was funded by Biotechnology Research Center (BRC), University of Dhaka, Bangla-

UniversePG I www.universepg.com desh. The authors sincerely acknowledge Dr. Abu Ashfaqur Sajib, Associate Professor, Genetic Engineering and Biotechnology Department, University of Dhaka for his significant contribution in designing the plant growth system.

\section{CONFLICTS OF INTEREST:}

The authors declare that they have no conflict of interest.

\section{REFERENCES:}

1) Alibert, G., Aslane-Chanabé, C. and Burrus, M., (1994). Sunflower tissue and cell cultures and their use in biotechnology. Plant phy- 
siology and biochemistry (Paris), 32(1), pp.31-44.

https://pascal-francis.inist.fr/vibad/index.php? action $=$ getRecordDetail \&idt $=4073427$

2) Dagustu N., (2018). In Vitro Tissue Culture $S$ tudies in Sunflower (Helianthus spp.), Ekin Journal of Crop Breeding and Genetics, 4(1): pp.13-21.

https://dergipark.org.tr/en/download/article-file/ 444841

3) Deglene L, Lesignes P, Alibert G, Sarrafi A., (1997). Genetic control of organogenesis in cotyledons of sunflower (Helianthus annuus).

Plant cell, tissue and organ culture, 48: pp.127-130.

https://doi.org/10.1023/A:1005803415142

4) Fiore, M.C., Trabace, T. and Sunseri, F., (1997). High frequency of plant regeneration in sunflower from cotyledons via somatic embryogenesis. Plant Cell Reports, 16(5), pp. 295-298.

https://doi.org/10.1007/BF01088284

5) Firoz, M.A., Uddin ME., Amin, R., Razzak, M.A., Manik, M.A. and Khatun, M.M., (2016). Studies on the effect of various sterilization procedures for in vitro seed germination and successful micropropagation of Cucumis sativus. International J. of Pure \& Applied Bioscience, 4(1): 75-81.

https://doi.org/10.18782/2320-7051.2226

6) Giovannelli, A., Giannini, R., Bennici, A. and Mori, B., (2004). In vitro organogenesis of chestnut (Castanea sativa Mill.) cotyleodon explants: responses to growth regulators and developmental aspects. In Vitro Cellular \& Developmental Biology-Plant, 40(5), pp. 509514.

https://doi.org/10.1079/IVP2004561

7) Gürel, E. and Kazan, K., 1998. Development of an efficient plant regeneration system in sunflower (Helianthus annuus L.). Turkish Journal of Botany, 22(6), pp. 381-388.

https://journals.tubitak.gov.tr/botany/issues/bot98-22-6/bot-22-6-3-98026.pdf

8) Hewezi, T., Jardinaud, F., Alibert, G. and Kallerhoff, J., (2003). A new approach for efficient regeneration of a recalcitrant geno- type of sunflower (Helianthus annuus) by organogenesis induction on split embryonic axes. Plant cell, tissue and organ culture, 73(1), pp. 81-86. https://doi.org/10.1023/A:1022689229547

9) Khatun M. M., Tanny T., Abdur. M. Razzak, Firoz Alam M, Ekhlas Uddin M, Ruhul Amin, and Yesmin S., (2016) Standardization of in vitro sterilization procedures for micropropagation of ginger (Zingiber officinale Rosc.), International J. of Applied Biology and Pharmaceutical Technology, 7(1): pp. 131-137. http://www.ijabpt.com/pdf/32012-M.\%20M.\% 20Khatun.pdf

10) Moghaddasi, M.S., (2011). Sunflower tissue culture. Advances in Environmental Biology, pp.746-756.

https://link.gale.com/apps/doc/A256365703/AO

NE? $\mathrm{u}=$ anon $\sim \mathrm{f} 84 \mathrm{a} 8 \mathrm{c} 61 \&$ sid=googleScholar\& $\mathrm{xid}$ $=01474 \mathrm{a} 9 \mathrm{f}$

11) Pourhosseini, L., Kermani, M.J., Habashi, A.A. and Khalighi, A., (2013). Efficiency of direct and indirect shoot organogenesis in different genotypes of Rosa hybrida. Plant Cell, Tissue and Organ Culture (PCTOC), 112(1), pp. 101-108.

https://doi.org/10.1007/s11240-012-0210-1

12) Sarrafi, A., Bolandi, A.R., Serieys, H., Bervillé, A. and Alibert, G., (1996). Analysis of cotyledon culture to measure genetic variability for organogenesis parameters in sunflower (Helianthus annuus L.). Plant Science, 121(2), pp. 213-219.

https://doi.org/10.1016/S0168-9452(96)04518-9

13) Shahen MZ, Mahmud S, Uddin ME and Alam MS., (2019). Effect of antibiotic susceptibility and inhibitory activity for the control of growth and survival of microorganisms of extracts of Calendula officinalis, Eur. J. Med. Health Sci. 1(1), pp. 1-9. https://doi.org/10.34104/ejmhs.0190109

14) Sujatha, M., Vijay, S., Vasavi, S., Sivaraj, N. and Rao, S.C., (2012). Combination of thidiazuron and 2-isopentenyladenine promotes highly efficient adventitious shoot regeneration from cotyledons of mature sunflower (Helianthus annuus L.) seeds. Plant Cell, 
Tissue and Organ Culture (PCTOC), 111(3), pp. 359-372.

https://doi.org/10.1007/s11240-012-0202-1

15) Taški-Ajduković, K.J. and Vasić, D.M., (2005). Different sterilization methods for overcoming internal bacterial infection in sunflower seeds. Zbornik Maticesrps keza prirodnenauke, (109), pp. 59-64.

http://www.doiserbia.nb.rs/img/doi/0352-4906/ 2005/0352-49060519059T.pdf

16) Wingender, R., Henn, H.J., Barth, S., Voeste, D., Machlab, H. and Schnabl, H., (1996). A regeneration protocol for sunflower (Helianthus annuus L.) protoplasts. Plant cell reports, 15(10), pp.742-745.

https://doi.org/10.1007/BF00232219

17) Zhu, M.L., Wang, J., Yu, Y., Liu, S.J. and Wei, Z.M., (2007). Efficient organogenesis and plantlet regeneration in the timber species Cunninghamia lanceolata (Lamb.) Hook. In Vitro Cellular and Developmental BiologyPlant, 43(5), pp. 449-455.

https://doi.org/10.1007/s11627-007-9092-z

Citation: Islam K, Ahmed T, and Sharmin T. (2021). In vitro growth of sunflower (Helianthus annuus) via direct organogenesis. Am. J. Pure Appl. Sci., 3(3), 60-64. https://doi.org/10.34104/ajpab.021.060064 @ @ ( ) 